\title{
Contextualised, not Neoliberalised Professionalism in Early Childhood Education and Care: Effects of Prescribed Notions of Quality on Educator Confidence in Australia
}

Marg Rogers ${ }^{a}$

\author{
Received \\ Revised \\ Accepted \\ $\mathrm{DOI}$ \\ 3 February 2021 \\ 16 February 2020 \\ 31 March 2021 \\ 10.26822/iejee.2021.211 \\ aMarg Rogers, School of Education University of \\ New England Armidale, NSW 2351 AUSTRALIA \\ E-mail: mbaber@une.edu.au \\ ORCID: https://orcid.org/0000-0001-8407-7256
}

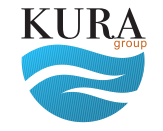

Copyright (C)

www.iejee.com

ISSN: 1307-9298

(c) 2021 Published by KURA Education \& Publishing. This is an open access article under the CC BYNC- ND license. (https://creativecommons.org/ licenses/by/4.0/)

\begin{abstract}
There is a standardised neoliberal inspired notion of what professionalism entails for early childhood educators. These standards tend to infiltrate much of the literature, reporting and pre-service educator training, creating a notion that educators are never quite good enough at what they do. Although constant reflection and aiming for excellence are strongly held Western ideals, the effect on educator confidence and their ability to recognise their own strengths and achievements can be real. This discussion paper seeks to challenge the idea that good quality early childhood practice can always be identified and standardised, arguing the need for professional discretionary decision-making in order to adjust practice to context. Drawing on an example from an Australian service, where knowledge, care, partnership and support for potentially vulnerable families to support their children was highly valued by parents, it illustrates that such qualities can go unrecognised by the staff themselves. What we risk losing when we prescribe what quality entails will be of interest to educational leaders, researchers and those who teach pre-service educators.
\end{abstract}

Keywords:

Professionalism, Qualitative Research, Neoliberalism, Early Childhood, Military Families, Education Policy, Mosaic Approach

\section{Introduction}

T he notion of professionalism in early childhood education and care (ECEC) is an important one because it affects key stakeholders, and much is at stake. Stakeholders include children, educators, employers, pre-service teacher educators and the community. Aspects of professionalism in Australia, including pay, status, unpaid hours and burnout impacts the educator turnover rate which is very high. In turn, this impacts all stakeholders because it negatively affects the quality of education and care because of the 


\section{iejee}

importance of secure relationships with caregivers with young children (Sims, 2011). High staff turnover can be very expensive and challenging for employers because they have to spend more time training new staff and reassuring families they can adequately staff their service. Indeed, parents consider staff commitment and staff who experience job satisfaction as a marker of a quality service (Fenech, 2012).

It is questionable whether professionalism can be standardised across the many contexts, communities, families and children, that ECEC encompasses. There is now a standardised neoliberal notion of what this entails that is present in much of the literature, standards, policy documents, frameworks, reports and pre-service educator training, according to Sims (2017). This notion often directs educators' work (Grant, Danby, Thorpe, \& Theobald, 2016; Hunkin, 2017) and could potentially undermine educator confidence as they strive for constant reflection and improvement, Western ideals that are glorified in neoliberalism. When we qualify and quantify quality, there is a risk that contextual variations of quality are unrecognised. This paper argues that educator professionalism needs to be viewed within the context of ECEC so practice is adapted to suit each unique environment, community, including the parents and children, and gives an example of how this was achieved in one setting.

\section{Neoliberal framework}

Neoliberal ideology is ubiquitous in 'laws, policies and programming at the international, national and local levels' (MacNaughton \& Frey, 2015, p. 17). No longer confined to Western countries, the ideology brings the world together in a unified global economy with one method of production (McLaren, 2005). Described by Chomsky (1999, p. 11) as the 'immediate and foremost enemy of genuine and participatory democracy', neoliberalism is a style of governance that elevates free market consumerism and capitalism. Faith is put in the marketplace to control outcomes, rather than governmental responsibility, control and expenditure to create equitable outcomes. Labelled by McLaren (2005, p. 5) as 'dangerous', neoliberalism values competition and places people in competition with each other, rather than appealing to their altruistic tendencies that are a part of human communities and experiences (Monbiot, 2019). It is a type of capitalism that is 'untrammelled' in its' quest for profits, so it does not need to be held accountable to anybody except shareholders who only require profits (Dahlberg \& Moss, 2005, p. 36). The neoliberal model views the state as inefficient and incapable of delivering services and state regulation as unwanted interference (Penn, 2002). Neoliberalism places blame for societies' ills on the vulnerable and distracts people with consumerism to make it easier to advance the policies and agendas of those with power (Chomsky, 1999, 2016). 'Instead of citizens, it produces consumers. Instead of communities, it produces shopping malls' Chomsky claims (1999, p. 11).

More than just an economic model, it is a way of governance, policymaking, political narrative deriving from the one ideology (Blackmore, 2019). While neoliberalism can produce high, but unstable, profit growth it seems to create a similar trend in social problems (Dahlberg \& Moss, 2005). Although it is an economic model, neoliberalism is pervasive and has become deep rooted (Moss, 2014). It 'seeks to spread its values and practices into every aspect of life' (Dahlberg \& Moss, 2005, p. 39), and has become a 'metanarrative that extends into every facet and niche of life' (Moss, 2014, p. 64). This means that systems such as education, healthcare, welfare and social work that were created from very different philosophies are struggling with the application of a model that is fundamentally a misfit (Rogers, Dovigo, \& Doan, 2021).

Neoliberalism also creates a complex system where managerialism excels (Giroux, 2013). Management is quite different to managerialism. Management is necessary because it involves the organisation of people's efforts to run an organisation successfully. Managerialism is where professional managers are relied upon or are viewed as necessary to manage worker's efforts, despite the competence and confidence of the workers. Managerialism does not mean that the worker is well looked after. Indeed, the worker is often distrusted therefore needing additional levels of management direction creating micromanagement, according to Giroux (2013; 2015). In this vain, managers frustrate workers by creating excessive busywork which is justified by the need for compliance and record keeping, taking them away from the activities they were trained for and want to do (Rogers, Sims, Bird, \& Elliott et. al., 2020). There has been an assumption that the managerial reforms that may have been successful in other sectors, will automatically suit educational settings, justifying market solutions to solve social ills (Exley, Braun, \& Ball, 2011).

This type of micromanagement often results in minutely detailed documents and checklists which take up inordinate amounts of worker's time to read and enact (Bradbury, 2012; Brown, 2015). Additionally, these documents and frameworks may inadvertently hamper innovation, individual creativity, contextual variations and a critique of the ideologies they represent or what they are trying to create (Sims \& Waniganayake, 2015). Within early childhood contexts, Millei and Kallio (2018, p. 43) explain that 'ECEC settings are inherently political' and policies and curriculum documents cannot be made independently of politics. Indeed, educators are uncomfortable with 
'business and politically motivated approaches' (Breacháin \& O'Toole, 2013, p. 415) and do not want to use assessment, pedagogy and curriculum designed by others (Hursh, 2007). Whilst the neoliberal narrative positions this as the most effective for productivity and high standards, the experiences of workers is often the opposite as they struggle with the way this hegemony affects their practice (Hursh, 2007).

\section{The impact of neoliberalism, educators' identity and their work in early childhood}

\section{An Australian example}

Neoliberalism has impacted the ECEC field, including educators' work and their identity as education becomes a commodifiable service (Moss, 2014). According to Moss (2014), it is too simplistic to say ECEC has become a function of the dominant economic model, but its influences are pervasive and complex. Grant et al. (2016) explains that there are huge 'disjunctures between teachers' experiences and policy intent' (p. 44), resulting in time pressure and increased documentation, along with stress around accountability from external sources. In turn, this can create work practices that are unsustainable and can result in educator burnout (Grant et al., 2016). As Maloney et al. (2019) explains, professionalisation of ECEC is based on 'discretionary decision making that is premised upon an accepted body of knowledge' and 'neoliberalism imposes constraints from on top, identifying through various forms of curricula, legislated standards, and policies what is appropriate and desirable practice' (p. 1). There has been a dramatic increase in the number of ECEC policy documents, frameworks, and standards in the past decade in Western countries, according to Hunkin (2017). Often the documents are so comprehensive another document is published to help explain the original document in practical terms. This is often called 'A guide to .....' or 'The handbook for ..... For example, Being, Belonging and Becoming: The Early Years Learning Framework (Department of Education Employment and Workplace Relations [DEEWR], 2009) was released in 2009 as a 51-page document. By 2010, a 150-page document was released called Educators Being, Belonging and Becoming: An Educators' Guide to the Early Years Learning Framework (DEEWR, 2010). It is not to say that any of these documents are poorly thought out, badly written, or were composed with any evil intent by the authors or authorities. That said, reflection is needed to think why over 200 pages were needed in the first place and how they have impacted educators' work within the sector. Similar to many Western countries, Australia has an increased number of education curriculum frameworks (Grant et al., 2016). For example, Being, Belonging, Becoming: The Early Years Learning Framework, (DEEWR, 2009), along with the Australian Curriculum (Australian
Curriculum Assessment and Reporting Authority, 2019) and each state curriculum, for example New South Wales (see https://educationstandards.nsw.edu.au/ wps/portal/nesa/k-10/years/kindergarten). While the latter two are generally related to schools, in recent years they have added early childhood years within the frameworks. Additionally, there are accreditation requirements (Australian Children's Education and Care Quality Authority, 2011; Australian Children's Education and Care Quality Authority, 2012) and national teacher standards (see https://www.aitsl. edu.au/).

It is not within the scope of this paper to critique each framework and guide however, questions have been raised to the way the EYLF strengthens neoliberal ideals (Millei \& Jones, 2014) and discusses cultural competence (Sims, 2014). Some have argued that educators have the scope within the framework to exercise professional autonomy, as they can with the EYLF framework. Although educators can use great scope, they may be more likely to stick with what is prescribed and explained, especially if they are less confident, or in an environment where they believe they are being constantly scrutinised, rather than encouraged. When we give educators large documents describing what quality is and how it looks in practice, are we inadvertently curtailing their own forays into quality practice that suits their own context? If they do use initiative to provide quality care unique to their context, are they able to recognise it?

Interestingly, within the combined 201 pages of the EYLF and the Educators Guide to the EYLF, there is no mention of the strengths an educator brings to the ECEC setting. The educators, however, are asked to recognise and expand children's strengths in both documents. Educators Being, Belonging, Becoming: The Educators' Guide to the EYLF also directs them to consider and debate the strengths of various theories and 'strengthen policy making, service delivery and practice, and continually monitor, reflect on and refine this process' (Department of Education Employment and Workplace Relations, 2010, p. 27). In the same document, there is a hint that all stakeholders bring strengths to the partnership, and that educators should be mindful of that, but there is no direct mention of their strengths. While it is pleasing that the documents focus on the children, it does seem that the importance of educator strengths seems to be lost. To recognise and build on children's strengths through planning, implementation and scaffolding, requires the educators to have strengths of curiosity, social intelligence, kindness, fairness and creativity if using the Via Institute's List of Strengths (Via Institute of Character, 2021). Working from the same strengths list, the other two activities listed above (around theories, policy and practice) would require educators to have self-regulation, teamwork, perseverance, judgement, 


\section{iejee $\sqrt{2}$}

love of learning and perspective. Thus, being an effective educator requires multiple strengths to be used simultaneously and it seems telling that they go unrecognised in documents such as these. It could be argued that these curriculum documents are not the place to recognise educator strengths, but it is hard to know where the recognition does belong. It certainly is not recognised in their Australian Government award wage (Fair Work Ombudsmen, 2020). Recognising and developing educator strengths is very important, especially for beginning educators, and assumptions cannot be made that every educator is getting encouragement and support within their service (Doan, 2014). When educators utilise their strengths, children, parents and the community benefit, however, attending to regulations may interfere with this process.

According to Bown and Sumsion (2007) accreditation requirements mean that educators 'may operate behind a metaphorical regulatory "fence" which contributes to their perceptions of safety but impinges on their professional freedom, integrity and passion for teaching' (p. 30), an unintended outcome of the documents. Indeed, there is a need to debate and question these frameworks (Millei \& Jones, 2014), guides and accreditation requirements because they affect children, educators, and ultimately, our society. These documents portray a particular image of the child and a future citizen of the world so they need to be critiqued (Galdames-Castillo, 2017). In an Australian study, Fenech, Sumsion, and Goodfellow (2006) found the increased regulations in ECEC services created increased needs for documentation, increased time pressure and increased administrative needs. Conversely, the increased regulations assisted engagement with parents and some management processes. Since these studies, the National Quality Framework has been introduced to provide 'a national approach to regulation, assessment and quality improvement for early childhood education and care and outside school hours care services across Australia' (ACECQA, 2020, para. 1). In studying the effects of this regulatory system on educators, Grant et al. (2016) remark on the detrimental 'personal effects of external accountabilities' (p. 44). In the same study, educators related the difficulty of interpreting other people's expectations in some of these documents, the extra unpaid hours spent fulfilling documentation requirements that caused family pressures, reduced contact time with the children and families during work hours, time pressure to still attend to other required tasks, the need to justify their work, the discomfort of giving into the different philosophy the requirements require, and dealing with comments from parents that they would prefer the educators work with the children, rather than documenting (Grant et al., 2016). When this type of work stress impacts family life, such as in the example of working after hours, it doubles the worker's stress according to Beattie (2019).

Within other education sectors, the influence of neoliberalism has meant: there has become a normalisation of working additional hours (Bottrell \& Keating, 2019), an expectation that work will need to be done outside of hours (Rea, 2018), work has intensified (Mayo, 2019) and an ideal worker is always working, even after hours and during annual leave (Sims, 2020). Thus, the reason behind the increase in the number of frameworks, policy documents, standards, guidelines and curriculum documents need to be questioned, and whether they are necessary and effective. We also need to question what the effects of all this extra documentation has on educator wellbeing and confidence. Standards of practice that have been externally created are a feature of ECEC in Australia, where educational leaders are supposed to ensure the educators and service are complying with the standards that are enforced through the national accreditation system (Maloney et al., 2019). Other countries question such standards and view them as a way to de-professionalise the industry as they allow governments to define quality and practice within their settings (Maloney et al., 2019) with their own agendas.

\section{Preparing human capital}

Within the early childhood sector, we need to be aware of those agendas and how they may have influenced our frameworks and curricula in the past, and potentially, the future. Sims (2017) and Sims and Waniganayake (2015) argue that there has been an increasing trend in Western countries toward higher levels of literacy and numeracy being emphasised within education documents, such as curricula, standards, frameworks and guides. This aligns with the ideas of children as future citizens who are required in the workforce, rather than working from a strengths-based framework where children's interests and strengths are utilised to create the best learning outcomes (Sims, 2017). Arguably, Being, Belonging, Becoming: The Early Years Learning Framework (EYLF)(Department of Education Employment and Workplace Relations, 2009) takes a more holistic approach. Indeed, we need to keep a strengths-based approach that builds on skills, encourages autonomy, enhances strengths and cultural knowledge and practices rather than working from a deficit-based perspective that focusses on fixing problems or gaps in skills (Green, McAllister, \& Tarte, 2004). According to Hursh (2007), a focus on literacy and numeracy diminishes the opportunity for education about rights and responsibilities and the development of the whole child. This is 'due to assumptions being made about their human capital potentials' rather than their development as human beings (Hunkin, 2017, p. 443). Fielding and Moss (2012) explain the way education prepares future neoliberal citizens, stating 
the dominant purpose is the production of autonomous subjects for an inescapable neoliberal world: the calculating and risk-bearing consumer, the flexible and lifelong-learning worker, homo economicus incarnate, equipped for a life of perpetual competition and instant responsiveness to the flickering of market signals (p. 1).

Therefore, arguments for these regulations and frameworks around increased quality could and should be questioned in relation to whose quality is foregrounded (Hunkin, 2017), the government's or the needs of the child. The dominant neoliberal assumption at work is that the market will promote quality, through competition and regulations (Maloney et al., 2019). According to Dahlberg, Moss, and Pence (2007), quality is constructed by individuals and groups based on their interests, values and beliefs.

The role and effects of neoliberalism in universities teaching pre-service early childhood educators

Australian pre-service educator training degrees require accreditation from the Australian Children's Education and Care Quality Authority (ACECQA) (2012) who implement the National Quality Framework (NQF) and the National Quality Standards (NQS). If it is a combined degree to teach birth to age 8 or birth to age 12, it also requires the relevant geographical state education regulatory authority. On another level, the university itself requires accreditation in accordance with the Higher Education Standards Framework (Tertiary Education Quality and Standards Agency, 2015)(TEQSA). The government justifies this in terms of quality outcomes for education and teaching through a complex web of quality assurance tools (Grant, et. al., 2016). Conversely, Hill (2004) argues that units within university courses have been simplified to keep the students, who have been positioned as customers, satisfied with the product (the qualification) and feel as though they are receiving value for money (Hil, 2012; McLaren, 2005). Indeed, MacNaughton and Frey (2015) note that in many Western countries, access to free higher education has reduced dramatically as fees increase and free spaces are based on merit. As education systems are marketised, the economy dictates educational aims and critical thought are suppressed as education becomes a 'sub-section of the economy' (McLaren, 2005, p. 6). Further to this, Sims (2020), Connell (2019) and Watts (2017) explain the inherent problems and far-reaching effects on education quality and academic freedom this type of over-regulation causes within universities. For example, Sims (2020) explains that neoliberal managerialism that is justified to promote quality, position the university worker as 'weak, obedient, and passive' (p. 140). In turn, this affects workers' identity as they are less able to do their work, but spend a lot of time justifying their work to ensure it meets management or government standards of perceived quality. This results in internalised oppression and the way workers view themselves, resulting in higher levels of stress within the workplace, negatively impacting the quality of their work (Rogers et. al., 2021). The stresses within the higher education sector impacts pre-service educators as they complete their teaching qualifications in a highly regulated, stressed environment with over-stretched staff.

\section{The effect on educators}

Within the ECEC sector, the effect of over-regulation in ECEC can result in a reduction in creativity and confidence and a moulding of what good early childhood practice should be (Rogers et. al., 2021). Accreditation, standards, guidelines and frameworks are prescriptive and part of the quality control of neoliberal inspired education policies, as described by McLaren (2005). Providing the quantity of evidence accreditation takes a great deal of educators' time, often reducing their ability to work with children's interests in a creative and relaxed manner which encourages innovation. This challenges educator identity and agency, because the documents can be perceived as authoritative and comprehensive, rather than guidelines of what quality might entail, which will vary greatly within the context of different services, demographics, communities and individual children. Maloney et al. (2019) assert that externally determined quality means educators become mere practitioners, further undermining their confidence. This is problematic, because ECEC practice is complex and nuanced (Cumming, Sumsion, \& Wong, 2015). Educators need to regulate and watch their behaviour to fit in with external mandates which 'sometimes means that working "with" the grain can be an uneasy experience' taking away 'the opportunity to exercise professional autonomy, and potentially undermine their professional confidence, engagement and satisfaction' (Cumming, Sumsion, \& Wong, 2013, p. 230). Educators' notions of quality are often shaped in terms of regulations and qualifications, as the study by Gibson (2015) found. Furthermore, McLaren (2005) describes the pressure on educational services to behave like businesses or risk being uncompetitive in a marketised system. Press, Woodrow, Logan, and Mitchell (2018) explain that in the neoliberal inspired marketisation of ECEC, the parent is placed as the consumer. In Australia and New Zealand, ECEC is the most privatised sector of education and market forces have changed the public discourse about the sector and shifted government and community responsibility onto the market (Press et al., 2018).

Over-regulation can also change the nature and focus of educator's work, to gather evidence for the large quantity of documentation required to prove their compliance and the quality of what they do (Grant, et. al., 2016). For example, reporting 


\section{iejee}

to parents, gathering documentary evidence to prove their competence and educational quality can often undermine engagement with children as the focus can easily slip away from the child to the documentation requirements (Rogers et. al., 2021). Educators can also lose their sense of 'professional integrity and responsibility' in the face of accreditation requirements that require 'unquestioning compliance' (Bown \& Sumsion, 2007, p. 47). It is questionable that the documentation improves or reflects the quality of education or care, but perhaps it satisfies authorities that important work is being done. The large quantitative study exploring the imposed quality measurements used in Australian long daycare centres by Fenech, Sweller, and Harrison (2010) concluded that quality measurements can inform policy, but they 'give conflicting messages about quality' and create many questions about the foundations of 'existing and changing' quality levels (p. 294). Indeed, Fenech (2012) argues against the dangers of imposing a positivist conceptualisation of quality that needs to be measured, and instead calls for a nuanced conceptualisation of quality in the ECEC sector. The findings of the Grant et. al. (2016) study show that since the implementation of the National Quality Framework, there are still many problems in this area. Therefore, there is a need to question the influences of the way quality is conceptualised, imposed and measured in ECEC and the way this has changed the work of educators and their belief that daily proof of children's engagement is required. Further, Vintimilla (2014) asserts that 'early childhood education serves the neoliberal project by maintaining the status quo through a sort of political apathy that is symptomatic of the diminishing criticality' (p. 85). How an imposed notion of quality affects educators' notions of their own work is of interest to the discussion in this paper.

\section{Challenging the idea of standardised practice in ECEC}

The increased presence of these neoliberal inspired documents in the ECEC sector raises a number of questions (Rogers et. al., 2021). The authors of these frameworks, standards and curriculum guidelines assume good quality ECEC practice can be identified and standardised, rather than being a complex, nuanced notion as Fenech (2011) describes. Whether the documents support educators and create better education and care is debatable, or, as Grantetal. (2016) suggests, they just create greater accountability and increased documentation. Perhaps these documents and high levels of accreditation jeopardise other ideals within ECEC, by using 'an economic lens ... (that) endangers the transformative and emancipatory potentials of ECEC' (Hunkin, 2017, p. 11). This paper argues a need and a responsibility to challenge this position and practice so that children have the best opportunities to thrive as recommended by Sims (2017). To further this argument, I present findings from research conducted with educators within a very specific community context which requires particular knowledge of the families' situation, their community and the ideals, expectations and associated challenges of the organisation that employs the parents.

\section{Research context}

The research project was entitled 'Young children's understandings and experiences of parental deployment within an Australian Defence Force (ADF) family' (Rogers, 2017a). Ethics approval for the study was gained through The University of New England and pseudonyms were given to all participants. The main research participants were 2-5-year old children, and the majority of these were attending an early childhood service in Australia, attached to a military base. The in-depth study had participants from eleven families, with nineteen children involved overall because a number of families had multiple children. Children needed to be from military families who had experienced parental deployment. From these participants, six case study children provided extra data that became a rich source of learning about their experiences and understandings of parental deployment. The families connected with the service were all recruited using convenience sampling. Parent consent and children's assent were used and all participants were able to withdraw from the study at any time. Additionally, children were able to opt in or out of various research activities as they pleased and their peers who were not involved in the study could do the research activities with them if they chose to, although their data was not used. Three extra families, not connected with the service were also involved to broaden the collection of data to include families from four different military bases and three different geographical states in total. Non-ADF parents and early childhood educators were also participants. They provided data with informed consent, providing valuable clarification and verification of children's responses, and extra background information through informal chats, emails, telephone calls and sharing family photos. Data was analysed using thematic and narrative analysis.

The unique stressors for these families included frequent and prolonged parental separation due to training and deployment which generally lasted between three to nine months (Baber 2016; RogersBaber, 2017b). The families also experienced frequent relocation at least every two years, which is common for many military families (Brooks, 2011) throughout the world. Military organisations and families can be described as 'greedy organisations', both demanding devotion, time, energy and great sacrifices from their members (De Angelis \& Segal, 2015). When the two intersect, tensions arise and it is within this intersection 
that military families live (Segal, 1986). As shown in Figure 1, children can respond to parental deployment emotionally (Paris, DeVoe, Ross, \& Acker, 2010), socially (Hollingsworth, 2011), physically (Lester \& Flake, 2013) and cognitively (Chandra et al., 2009). This creates added strain on the parent at home and the returning parent when the family reunites (Rogers, Bird, \& Sims, 2019b). In order to answer the research question 'what are young children's understandings and experiences within an ADF family', a participatory research methodology was chosen.

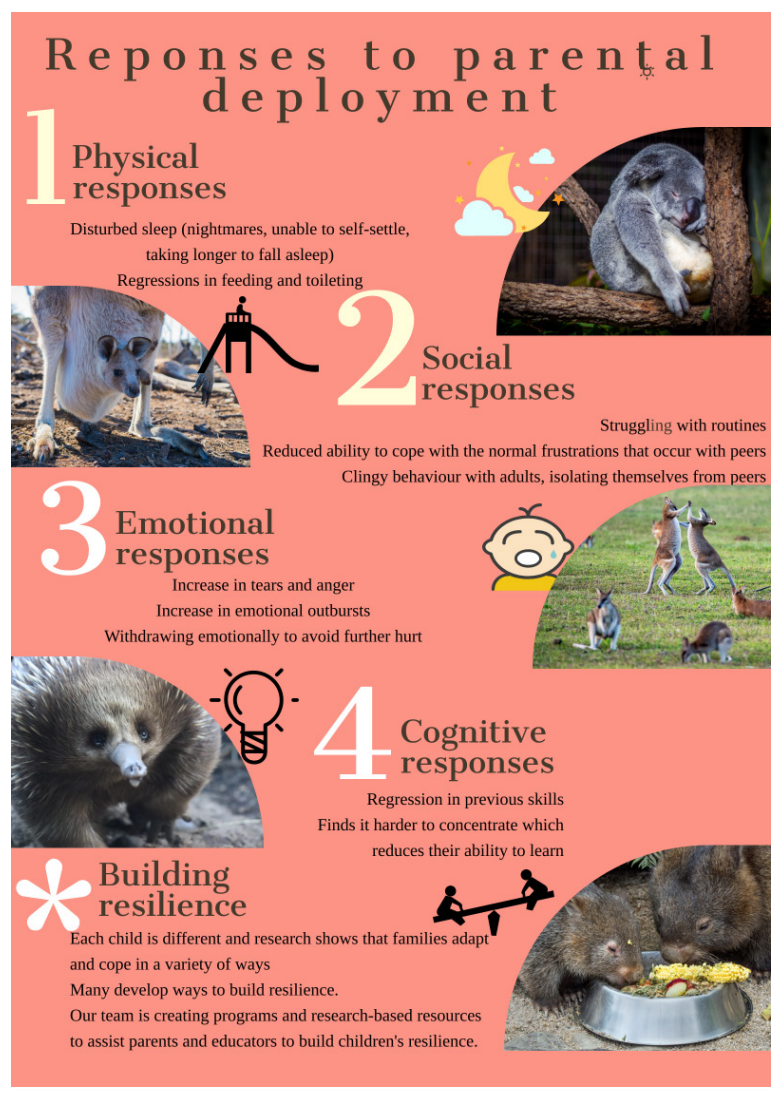

P PIKTOCHART

\section{Figure 1:}

Children's responses to parental deployment (Source: Rogers et. al., 2019b)

\section{Methodology}

The participatory research Mosaic approach was chosen to capture the voices of young children who had previously been marginalised in military family research in Australia and globally (Rogers \& Bird, 2020; Rogers, Bird, \& Sims, 2019). While research had been done with military families, the data about children was either secondary data from parents, or collected from a deficit-based psychological model, rather than a strengths-based resilience model (Rogers, 2017a). The framework for listening to children's voices was proposed by Clark and Moss (2011) and is based on three tenets, as displayed in Figure 2. Firstly, the framework asserts that children are adept communicators and are capable of making sense (Mazzoni \& Harcourt, 2013). Secondly, the framework states that children have a right for their opinions and voices to be heard as outlined by the United Nations (1989), which has been ratified by many countries, such as Australia, so therefore is subject to international law. Lastly, it states that children are knowledgeable about their own lives and issues that affect them (Clark \& Statham, 2005).

\section{A FRAMEWORK TO IISTEN TO CHILDREN'S VOICES \\ Using the Mosaic approach in participatory research}

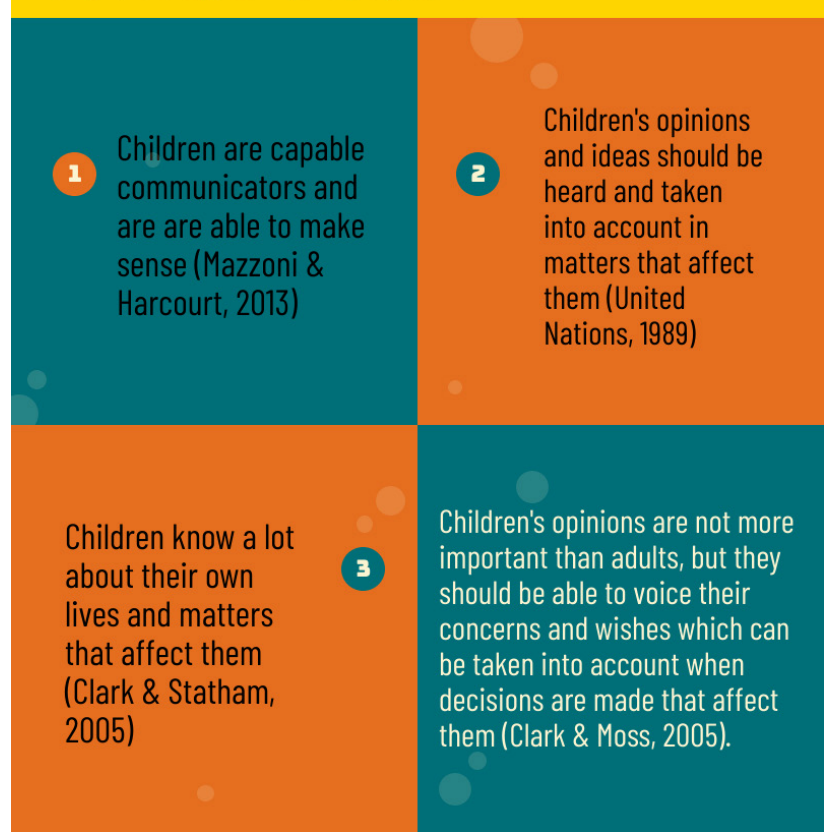

Figure 2:

A framework for listening to children's voices (Adapted from Clark \& Moss, 2011)

Using this framework, the voices of children were captured using a range of tools, including observations, chats, photo and story elicitation, discussions, artwork, craftwork, rhymes, raps, role and puppet play, photos the children took and instructed their parents to take, shared family photos and a researcher reflective journal (Rogers \& Boyd, 2020) as recommended by (Greenfield, 2011). Most research activities started with a reading of one of the storybooks the researcher had written about a family where a parent is away on deployment (e.g. Now that I am big: Anthony's story, Rogers, 2018b). This would act as a springboard for group discussions and the practical arts-based activities. I also gathered the voices of their non-ADF parents and their early childhood educators. These small pieces of data were grouped into themes using thematic analysis, then on reflection of all the themes, a clearer picture of what the children understood and experienced when their parent deployed. This is 


\section{iejee}

similar to a mosaic picture that is made up of small pieces of colour that is arranged in patterns, then when you get enough perspective from a distance, you can see the whole picture (see Figure 3). A socioecological lens was also applied to the findings, utilising the model by Bronfenbrenner $(1979,1986)$. To do this, each child from the case studies connections and supports were viewed and plotted within their socio-ecological model. This framed the discussions about the protective factors each child connected to.

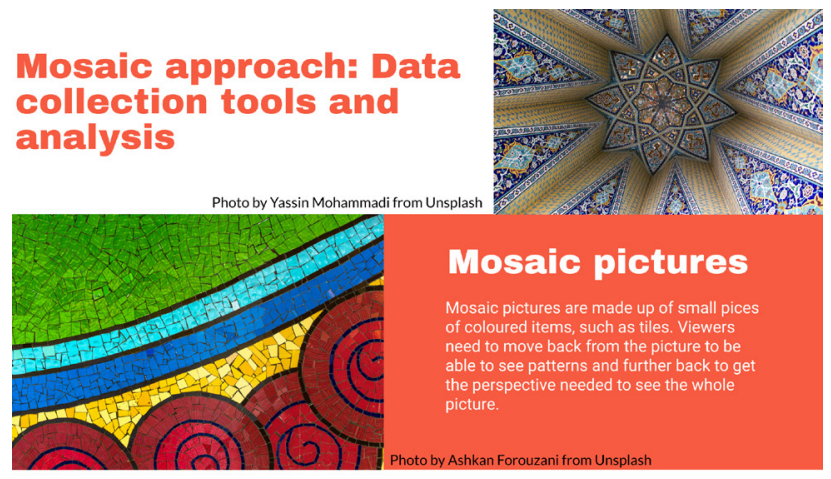

Chosen data collection tools

Observations

Informal chats

Artwork and craftwork

$\checkmark$ Puppet and role play

Photo elicitation

Storybook elicitation

$\checkmark$ Group chats

$\checkmark$ Photos the children took Shared family photos

Rhymes and rap

$\checkmark$ Researcher journal

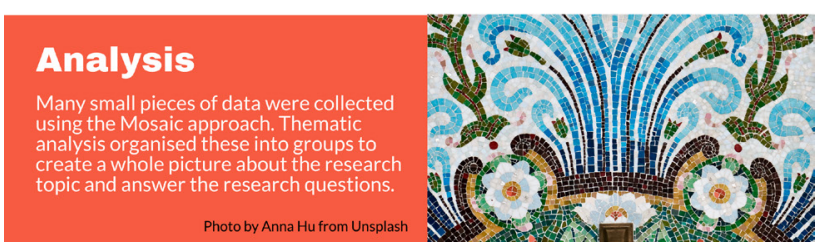

Figure 3:

Mosaic data collection tools and analysis

Results and links to ECEC and military family literature

'Simon leaves tonight for six week's training, and Bella (2-years old) has been just awful to him in the lead up to him going....Just yelling at him, refusing to cuddle him and saying she doesn't like him 'cause he's going and stuff like that. It's awful. I am so upset and Simon is devastated'. Parent 1

'The educators lent me books about emotions for Bella (2-years old), because she wasn't coping. The books really helped me work through strong emotions with her, like anger and sadness. Her behaviour really started to improve after that'. Parent 1
March 2021, Volume 13, Issue 4, 549-564

'I am a mess for the last two weeks (of deployment). I fear something might happen to him. It's when the shit happens, at the end'. Parent 1

'My hardest week is week 3 or 4 of deployment. I think it really sinks in then. When I am not coping, Emily's (2-years old) emotional state and mine are a bad mix. We sort of feed off each other. It helps me to cope if I just tell everyone I am doing it tough. I do that with my friends, my Facebook friends and Emily's educators. Emily's educators give extra support to us both and it really helps. They understand defence families'. Parent 2

'The educators at this centre really support them emotionally, I think. We thought of moving Cassie (3-years-old) when we moved houses, but both agreed, their understanding and support of defence kids is worth the extra drive'. Parent 3

The data revealed many themes within the project and the research question was answered. This paper does not discuss the answers to the overall research question, but concentrates on one particular theme, using the vignettes above, about the positive relationships children and parents had with the children's early childhood educators. This was also revealed in the literature by Hollingsworth (2011) who explains that positive relationships and social supports with others outside the family act as protective factors, coping strategies or buffers during stressful times in military families. The parents listed the educator's knowledge of military family needs as a major strength of the service and their ability to support the child and the family (Rogers-Baber, 2017b).

Parental deployment creates stress for families (Gewirtz, DeGarmo, \& Zamir, 2016; Siebler \& Goddard, 2014). The at-home parent needs to cope with their own feelings of grief and loss, as well as deal with the responses of children (Rogers, 2018a). These responses mean higher levels of attention and care are needed as the child struggles to cope with the sudden absence of their parent. Leaving the house is often very stressful, as the child might withdraw socially (Hollingsworth, 2011) and no longer wants to go to places they previously enjoyed, such as early childhood settings. So, the parent is often exhausted physically, sleep deprived, emotionally spent, and having to make extra effort to avoid social isolation. In turn, this can affect their ability to appropriately support their child(ren)(Cai, 2020). The ability of the educator to recognise and understand this stress, respond appropriately and offer support is key for the at-home parent (Rogers, 2020).

In this example, Bella's mother (Parent 1) reported that she received emotional support and empathy from educators for Bella and herself within the early childhood centre, something that was not identified through quality assurance processes. They loaned her resources that helped her explain some of the strong emotions that Bella was experiencing. These resources acted as springboards, giving them a way to talk about 
the emotional responses Bella was having when her father deployed. Arthur, Beecher, Death, Dockett, and Farmer (2018) state this is a marker of quality care as well as sensitivity to the diversity of family structures, challenges and experiences of families. Parents seek care for their infants and toddlers based on warm relationships and stress the importance of health and wellbeing (Ahnert, 2005). Additionally, Bella's parents matched their own underlying beliefs with the childcare service as Otto and Keller (2014) describe in their paper about alloparenting. Parents, educators, extended family and adult friends take on varying care roles forming multiple attachments for a child, which Ahnert (2005) calls alloparenting in humans. Although we do not know as yet the long-term effects of alloparenting through early childhood services, and the way they socially embed care, we do understand its' importance (Otto \& Keller, 2014).

Transitions, such as moving on to school, can disrupt the protective factors provided by relationships with ECEC educators. In one example, a parent communicated her fears around sending her child to a school nearby to where they lived because the teachers at some schools would not have the cultural knowledge and understanding of defence families. The children enrolled from the school were almost all from the general community, with only one or two from defence families. This was in contrast to the educators at the early childhood service who only taught children from military families. Additionally, Parent 3 communicated they had kept their child at the service despite moving suburbs and having to travel an extra 40 minutes every day to keep her at the service because the educator understood and supported military families. The mother revealed this decision was based on the professionalism of the staff who provided emotional support and understanding of the needs of children and families from the military community. Apart from transitioning to schools and moving suburbs, frequent relocations to other towns and cities inhibit these protective factors (De Pedro \& Astor, 2011) because new relationships with staff and peers need to be formed, along with adjusting to changes in practices, expectations and settings.

Early childhood educators need to develop respectful relationships with parents to best support the child (Newman \& Pollnitz, 2005). Emily's mother (Parent 2) valued the knowledge and understanding of military families and reported that they were a strong source of emotional source for both Emily and herself. This was achieved through respect, genuine empathy and authentic emotional support. Jennings (2014) articulates that educators have the important role of providing emotionally and socially supportive learning environments. Unlike in the US context, Australian educators are expected to learn about military families within their services because no culturally appropriate formal training or resources have been available. Due to the high level of turnover in the ECE sector, this is problematic. It is also challenging when a family is using a service who has had no previous experience in supporting military families. This lack of guidance is being addressed through the provision of free, research-based resources and programs for educators (and parents and family support workers) to be piloted in 2021 (see https://ecdefenceprograms. com/). So, the educator's responses to the families in this example (conducted prior to the creation of the programs), are remarkable.

In order to achieve quality relationships and the trust and loyalty of parents who transitioned in and out of the service as their families were moved about by the military, the educators at this service needed specific knowledge of the military culture and be willing to support it. For example, specific military commemorative days were observed at the service, for example, Anzac Day and Remembrance Day. They also included military uniforms in the dramatic play area, decorated the foyer with army colours, camouflage nets and toys dressed in military uniforms, and they included toys that were military themed in a toddler play area (Baber, 2016). They also supported the narratives the parents had developed with the children to help them explain when their parents were going away, and when they would return from deployment (Baber, 2016). Despite frequent relocations, educators needed to build rapport and partner with parents to know what was happening at home to assist them to support the child during times of transition (e.g. deployment and training). They needed high levels of empathy to assist children during the initial deployment and reunions because children responded emotionally, socially and physically as outlined in Figure 1. The educators also provided the non-deployed parent with additional support due to fatigue, and increased parenting and emotional stress.

Using the Via Institute of Character (2021) strengths list, this support required educators to demonstrate social intelligence, perspective, love of learning, judgement, curiosity, zest, perseverance, love, kindness, fairness, teamwork, leadership, hope, prudence and selfregulation. Again, this shows how complex and nuanced educators' work is and how many strengths are needed to do the work well. The most surprising finding was when I relayed the messages of the parents back to the educators, they were shocked. Despite their many years' experience in the ECEC sector, they had not recognised their own strengths, knowledge and value and were clearly unaware of the loyalty this engendered from the families. The educators' inability to recognise their own value is partly due to working in a figured world through the use of neoliberal inspired policies that make 


\section{iejee}

educators feel that they are never good enough, that they must constantly try to improve their practice. This figured world 'positions workers as incompetent, untrustworthy and in need of micromanagement to perform effectively' making it challenging to maintain a sense of self-efficacy or self-worth' (Sims, 2020). Indeed, Moore and Robinson (2016) and Rogers et. al., (2021) note that in neoliberal inspired micromanaged environments, workers lack confidence, fear doing anything that is not prescribed and feel undervalued. This makes it very difficult to ensure educators can resist these neoliberal influences and determine what is good practice, as described by (Maloney et al., 2019).

\section{Discussion about neoliberalism in ECEC}

The inability of these experienced educators to recognise and value what they did is deeply concerning and raises many questions about the neoliberal inspired context in which they work. While the neoliberal mantra of constant reflection and improvement may sound appealing, it may have it left us with educators who cannot see their own worth. The prescriptive standards, frameworks, curriculum and guidelines may not build the confidence and skills of educators because they are a form of neoliberalinspired micromanagement. The neoliberal worker, as described by Dahlberg and Moss (2005), is adaptive, flexible, self-reflective and self-analytical but clearly, in this situation, lacks confidence. It has made them only value what is prescribed, rather than determine what quality looks like in their own context. Workers who feel valued and competent tend to stay longer in their jobs, but the early childhood profession has a very high attrition rate in Australia, affecting the education and care of the children and the support given to parents.

Therefore, we need to challenge the idea that good quality ECEC practice can or should be identified and standardised (Maloney et al., 2019), and question why authorities are allowing the neoliberal agenda to unfold in the ECEC field (Dahlberg et al., 2007). As Macías (2015) notes, other related fields, such as social work are also being affected by the neoliberal agendas of regulatory bodies, education authorities and policy makers. She argues that

neoliberal market rationalities are sustained by discourses of practise standardization that reduce risk associated with social workers who either overstep professional boundaries or exercise personalized judgement. Discourses of standardization capture interpersonal and potentially unpredictable social work relationships within a rationality of objectivity, predictability, calculability and rational action' (Macias, 2015, pp. 256-257).

There is a need for professional discretionary decision making in order to adjust practice to context. If we challenge standardisation in the neoliberal context, it opens up opportunities to support educators. Unfortunately, neoliberalism is not a finished project, it is still unfolding within Western societies and its' affects are far reaching and may increase if we are not vigilant and resist their excesses (Macías, 2015). Neoliberalist documents consist of a very particular type of language, and language itself changes the way we think (Jones \& Hoskins, 2016). Although we may resist neoliberalism, most of us tend to take on aspects of it in the way we view ourselves and the way we work and act (Macías, 2015). Indeed, such language and philosophies become part of our figured world, that is our socially constructed understandings of our world (Cleland \& Durning, 2019) and how we behave and practice in that world. Cumming et al. (2015) remind us of the complexities and nuances of ECEC practice that are constructed between children, the context and broader regulatory environment. The way neoliberal ideologically inspired documents infiltrate our organisations makes them part of the organisational narratives that underpin mission statements, aims, goals, directives and priorities. Narratives are innately important to humans and we are attracted to them (Gleeson, 2012; Gottschall, 2012; Rogers, 2019, 2021). According to Monbiot (2019) they are the 'means by which we navigate the world. They allow us to interpret its complex and contradictory signals' (1.26 minutes).

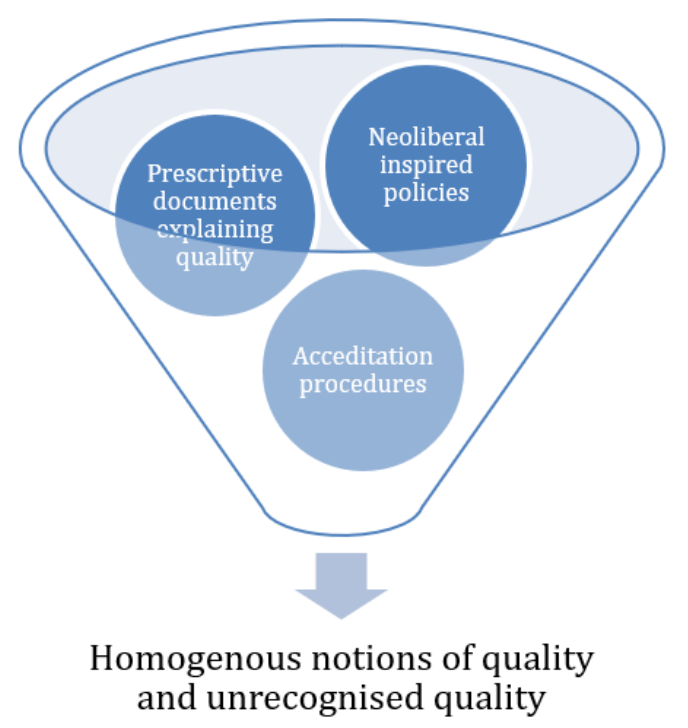

\section{Figure 4:}

The potential path to homogenous notions of quality and unrecognised quality

In this project, we can see that the educators had taken on the neoliberal narrative notion that quality and value is only what was prescribed in neoliberal ideologically inspired documents, rather than the quality they were providing in their unique context. This is summarised in Figure 4, where the neoliberal 
inspired policies, documents, accreditation systems can potentially create a homogenous notion of quality and an inability to recognise contextual quality. The educators failed to see the nuanced complexity of their work, as autonomous decisions were devalued by neoliberal inspired requirements, as explained by Cumming et al. (2015) and Cumming et al. (2013). The educators had also taken on the neoliberal logic that there is a need for constant improvement and that there is always more to be done, despite their best efforts (Mayo, 2019). This disempowering and disenchanting mantra is demonstrated by the educator's inability to value and recognise the quality in their own practice. Such devaluing of their work is worrying, given the low levels of pay and the high levels of attrition in the ECEC sector (Page, 2019), because high attrition and low job satisfaction affect all stakeholders.

\section{Limitations}

This was only one set of educators in one service and therefore cannot be applied to other setting. It is not assumed that the educators' lack of recognition of their own strengths and quality practices within their unique context is widespread. It does however, invite important discussion about prescribed notions of quality and how this might impact educators.

\section{Conclusion}

Therefore, we need to be vigilant and question the influence of neoliberalism on our educators and ECEC sector, or risk 'political apathy or conformism that keeps alive the neoliberal status quo and allows it to remain unthought' (Vintimilla, 2014). The dominant discussion in early childhood hides behind the guise of quality, but arises from neoliberal philosophy and a positive stance which requires technical application with managerial oversight (Dahlberg, Moss \& Pence, 2007). As Galdames Castillo (2017) explains 'ECEC has become one of neoliberalism's technologies for control and domination of children as a future workforce' (p. 171). Thus, many educators and pre-service educators have not known any other model than neoliberalism, so it is harder to identify the influence of neoliberal policies, or imagine another way of functioning (MacNaughton \& Frey, 2015; McLaren, 2005). Despite this, we need to encourage educators to recognise and value their unique strengths within their own unique contexts and communities. In turn, this encourages them to recognise and value the strengths of their colleagues within their unique context. Hunkin (2017, p. 452) states

'a concerted effort by ECEC stakeholders is needed in order to break down the taken-for-granted authority of the dominant assumption that quality is universal, measurable factors. Spaces need to be created for the quality of ECEC settings to be acknowledged as a contestable, complex notion, likely to differ in meaning across populations and time!

Neoliberalism was designed as an economic model, which has now been applied to other aspects of society, such as education. Unfortunately, the system does not fit well and has had a deep impact in the ECEC sector and is often reasoned as a way to improve quality, which is debatable. It has been responsible for increased busyness associated with the work of educators as they strive for constant improvement, reflection and accreditation, constantly proving their worth and ability against pre-determined prescribed measures. This busyness itself is a distraction that assists the neoliberal agenda to unfold. Indeed,

'as long as the general population is passive, apathetic, and diverted ... then the powerful can do as they please, and those who survive will be left to contemplate the outcome' (Chomsky, 2016, p. 56).

We need a concerted effort to raise awareness, discuss these issues, and resist the problematic effects of neoliberalism's infiltration into education (Hil, 2012). Similarly, Giroux (2015) states that resistance to neoliberalism is 'not a luxury but a necessity' (p. 200), and Press et al. (2018) stress the need to 'reclaim the purpose of education' (p. 337). Within ECEC, educators and pre-service educators need to feel valued and competent so they can continue their work in their own unique contexts and recognise and value contextualised quality and professionalism. Educator's confidence and feelings of competence will hopefully assist them to have long and rewarding careers in this important profession and go on supporting young children and families.

\section{References}

Ahnert, L. (2005). Parenting and alloparenting: The Impact on attachment in humans. In C. Carter, K. Ahnert, S. Grossmann, M. Hrdy, M. Lamb, S. Porges, \& N. Sachser (Eds.), Attachment and bonding: A New systhesis. (pp. 229-244). Cambridge, MA: MIT Press.

Arthur, L., Beecher, B., Death, E., Dockett, S., \& Farmer, S. (2018). Programming and planning in early childhood settings. South Melbourne, Australia: Cengage.

Australian Children's Education and Care Quality Authority. (2011). Guide to the National Quality Standard. Canberra, ACT: Australian Children's Education and Care Quality Authority. Canberra, ACT, Australia: Australian Children's Education and Care Quality Authority Retrieved from http://acecqa.gov.au/storage/3\%20 -\%20Guide\%20to\%20the\%20National\%20 Quality\%20Standard\%2OFINAL.pdf 
Australian Children's Education and Care Quality Authority. (2012). National Quality Framework. Retrieved from www.acecqa.gov.au/nationalquality-framework

Australian Children's Education and Care Authority. (2020). About the National Quality Framework. Retrieved from https://www.acecqa.gov.au/ national-quality-framework

Australian Curriculum Assessment and Reporting Authority. (2019). Foundation to 10 Curriculum. Media Arts. Retrieved from https://www. australiancurriculum.edu.au/f-10-curriculum/ the-arts/media-arts/

Baber, M. (2016). Narrative, Acculturation and Ritual: Themes from a Socio-ecological Study of Australian Defence Force Families Experiencing Parental Deployment. Children Australia, 41(2), 141-153. doi: http://dx.doi.org/10.1017/cha.2016.8

Beattie, P. (2019). The Road to Psychopathology: Neoliberalism and the Human Mind. Journal of Social Issues, 75(1), 89-112. doi:10.1111/josi.12304

Blackmore, J. (2019). Femminism and neo-liberalism: Contesting education's possibilities. Discourse: Studies in the cultural politics of education, 40(2), 20. doi:10.1080/01596306.2019.1569877

Bottrell, D., \& Keating, M. (2019). Academic wellbeing under rampant managerialsm. In D. Bottrell \& C. Manathunga (Eds.), Resisting neoliberalism in higher education (pp. 157-178): Springer International Publishing.

Bown, K., \& Sumsion, J. (2007). Voices from the other Side of the Fence: Early Childhood Teachers' Experiences with Mandatory Regulatory Requirements. Contemporary Issues in Early Childhood, 8(1), 30-49. doi:10.2304/ ciec.2007.8.1.30

Bradbury, A. (2012). 'I Feel Absolutely Incompetent': Professionalism, Policy and Early Childhood Teachers. Contemporary Issues in Early Childhood, 13(3), 175-186. Retrieved from https:// journals.sagepub.com/doi/abs/10.2304/ ciec.2012.13.3.175. doi:10.2304/ciec.2012.13.3.175

Breacháin, A. Ó., \& O'Toole, L. (2013). Pedagogy or politics?: cyclical trends in literacy and numeracy in Ireland and beyond. Irish Educational Studies, 32(4), 401-419. Retrieved from https://doi.org/10.1 080/03323315.2013.851441. doi:10.1080/03323315.2 013.851441
Bronfenbrenner, U. (1979). The ecology of human development. Cambridge, MA: Harvard University Press.

Bronfenbrenner, U. (1986). Ecology of the family as a context for human development: Research perspectives. Developmental Psychology, 22(6), 723-742.

Brooks, J. (2011). The process of parenting (8th ed.). New York: McGraw-Hill.

Brown, C. P. (2015). Conforming to reform: Teaching prekindergarten in a neoliberal early education system. Jounral of Early Childhood Research, 13(3), 236-251. doi:10.1177/1476718X14538602

Cai, Q. (2020). Emotional Distress, Deployment Length, and Change in Parental efficacy after a Military Parenting Program: A Dyadic Longitudinal Model. (Master of Arts), University of Minnesota.

Chandra, A., Lara-Cinisomo, S., Jaycox, L. H., Tanielian, T., Burns, R. M., Ruder, T., \& Han, B. (2009). Children on the homefront: The experience of children from military families. Pediatrics, 125(1), 16-25. Retrieved from http://www.ncbi.nlm.nih.gov/ pubmed/19969612. doi:10.1542/peds.2009-1180

Chomsky, N. (1999). Profit over people. New York, NY: Seven Stories Press.

Chomsky, N. (2016). Who rules the world? New York, NY: Hamish Hamilton (Penguin Books).

Clark, A., \& Moss, P. (2011). Listening to young children: The mosaic approach. London, UK: National Children's Bureau.

Clark, A., \& Statham, J. (2005). Listening to young children: Experts in their own lives. Adoption \& Fostering, 29(1), 45-56. doi:10.1177/030857590502900106

Cleland, J., \& Durning, S. (2019). Education and service: how theories can help in understanding tensions. Medical Education, 53, 42-55. doi:10.1111/medu.13738

Connell, R. (2019). The good university. What universities actually do and why its time for radical change. Melbourne, Australia: Monash University Publishing.

Cumming, T., Sumsion, J., \& Wong, S. (2013). Reading between the Lines: An Interpretative MetaAnalysis of Ways Early Childhood Educators Negotiate Discourses and Subjectivities Informing Practice. Contemporary Issues in 
Early Childhood, 14(3), 223-240. doi:10.2304/ ciec.2013.14.3.223.10.2304/ciec

Cumming, T., Sumsion, J., \& Wong, S. (2015). Early childhood practice and refrains of complexity. Early Years: An International Research Journal, 35(1). doi:10.1080/09575146.2014.937796

Dahlberg, G., \& Moss, P. (2005). Ethics and politics in early childhood education(pp. 6 pages downloaded). Retrieved from https://books. google.com.au/books?id=mOGCAgAAQBAJ\& $|p g=p p 1 \& d q=d a h| b e r g \% 20$ early\%20childhood\%20neoliberal\& Ir\&pg=PP1\#v=onepage\&q=dahlberg\%20 early\%20childhood\%20neoliberal\&f=false

Dahlberg, G., Moss, P., \& Pence, A. (2007). Beyond Quality in Early Childhood Education and Care: Languages of Evaluation(pp. 7 pages downloaded).

De Angelis, K., \& Segal, M. W. (2015). Transitions in the military and the family as greedy institutions. In R. Moelker, M. Andres, G. Bowen, \& P. Manigart (Eds.), Military families and war in the 21st century (pp. 22-42). Oxon, UK: Routledge.

De Pedro, K. M. T., \& Astor, R. A. (2011). The children of military service members: Challenges, supports and future educational research. Review of Educational Research, 81(4), 566-681.

Department of Education Employment and Workplace Relations. (2009). Belonging, being and becoming: The early years learning framework (EYLF). Canberra, Australia: Department of Education, Employment and Workplace Relations

Department of Education Employment and Workplace Relations. (2010). Educators Belonging, Being. Becoming: The educators' guide to the early Years learning framework. Barton, Australia: Australian Government Retrieved from https:// docs.education.gov.au/system/files/doc/ other/educators_guide_to_the_early_years_ learning_framework_for_australia.pdf

Doan, L. (2014). The Early Years: An Exploration of the Experiences and Needs of Novice Early Childhood Educators in British Columbia. (Doctorate of Education), University of Calgary, Calgary, Canada. Retrieved from http:// theses.ucalgary.ca/bitstream/11023/1606/2/ ucalgary_2014_Doan_Laura.pdf

Exley, S., Braun, A., \& Ball, S. (2011). Global education policy: networks and flows. Critical Studies in Education, 52(3), 213-218. Retrieved from https:// doi.org/10.1080/17508487.2011.604079. doi:10.108 0/17508487.2011.604079

Fair Work Ombudsman. (2020). Pay Guide Children's Services Award. Retrieved from https://www. fairwork.gov.au/ArticleDocuments/872/ childrens-services-award-ma000120-payguide.pdf.aspx

Fenech, M. (2011). An Analysis of the Conceptualisation of 'Quality' in Early Childhood Education and Care Empirical Research: promoting 'blind spots' as foci for future research. Contemporary Issues in Early Childhood 12(2). doi:10.2304/ ciec.2011.12.2.102

Fenech, M. (2012). Discerning childcare quality: parents as potential informants of policy beyond regulation. Critical studies in education, 53(3), 327-345.

Fenech, M., Sumsion, J., \& Goodfellow, J. (2006). The Regulatory Environment in Long Day Care: A 'double-edged sword' for early childhood professional practice. Australasian Journal of Early Childhood, 31(3), 49-58. Retrieved from https://journals.sagepub. com/doi/abs/10.1177/183693910603100308. doi:10.1177/183693910603100308

Fenech, M., Sweller, N., \& Harrison, L. (2010). Identifying high-quality centre-based childcare using quantitative data-sets: what the numbers do and don't tell us. International Journal of Early Years Education, 18(4). Retrieved from https:// doi.org/10.1080/09669760.2010.531615. doi:10.108 0/09669760.2010.531615

Fielding, M., \& Moss, P. (2012). Radical democratic education. Paper presented at the American Socialogical Association, Denver, CO

Galdames Castillo, X. (2017). "Caballito blanco, jvuelve pa' tu pueblo!": Troubling and reclaiming the historical foundations of Chilean early childhood education. Global Studies of Childhood, 7(2), 159-178. doi:oOr.g1/107.171/2770/423064316016016 71770033843

Gewirtz, A. H., DeGarmo, D. S., \& Zamir, O. (2016). Effects of a Military Parenting Program on Parental Distress and Suicidal Ideation: After Deployment Adaptive Parenting Tools. Suicide Life Threat Behaviour, 46 Suppl 1, S23-31. doi:10.1111/sltb.12255

Gibson, M. (2015). "Heroic Victims": Discursive Constructions of Preservice Early Childhood Teacher Professional Identities. 36(2), 142-155. do i:10.1080/10901027.2015.1032449

Giroux, H. (2013). Neoliberalism's war against teachers 
in dark times. Cultural Studies: Critical Methodologies, 13(6), 458-468.

Giroux, H. (2015). Dangerous thinking in the age of the new authoritarianism. Boulder, CO: Paradigm Publishers.

Gleeson, L. (2012). Writing like a writer: Teaching narrative writing. Sydney, Australia: Primary English Teaching Association of Australia.

Gottschall, J. (2012). The storytelling animal: How stories make us human. New York, NY: Houghton Mifflin Harcourt Publishing Company.

Grant, S., Danby, S., Thorpe, K., \& Theobald, M. (2016). Early childhood teachers' work in a time of change. Australasian Journal of Early Childhood, 41(3), 38 - 45.

Green, B. L., McAllister, C. L., \& Tarte, J. M. (2004). The Strengths-Based Practices Inventory: A Tool for Measuring Strengths-Based Service Delivery in Early Childhood and Family Support Programs. Families in Society, 85(3), 326-334. Retrieved from https://doi.org/10.1177/104438940408500310.

Greenfield, C. (2011). Personal reflection on research process and tools: Effectiveness, highlights and challenges using the mosaic approach. Australasian Journal of Early Childhood, 36(3), 109-116.

Hil, R. (2012). Whacademia: An insiders account of the troubled university. Sydney, Australia: New South Publishing.

Hill, D. (2004). Books, banks and bullets: Controlling our minds - the global project of imperialistic and militaristic new-liberalism and its effects on education policy. Policy Futures in Education, 2(3 \& 4), 504-522. doi:10.2304/pfie.2004.2.3.6

Hollingsworth, W. G. (2011). Community family therapy with millitary families. Contemporary Family Therapy, 33, 215-228. doi:10.1007/s10591-011-9114-8

Hunkin, E. (2017). Whose quality? The (mis)uses of quality reform in early childhood and education policy. Journal of Education Policy, 33(4), 443456. doi:10.1080/02680939.2017.1352032

Hursh, D. (2007). Assessing No Child Left Behind and the rise of neoliberal education policies. American Educational Research Journal, 44(3), 493-518. Retrieved from https://www.jstor.org/ stable/30069426.

Jennings, P. (2014). Early childhood teachers' wellbeing, mindfulness, and self-compassion in relation to classroom quality and attitudes to wards challenging students. Mindfulness. doi:10.1007/s12671-014-1312-4

Jones, A., \& Hoskins, T. K. (2016). A Mark on Paper: The Matter of Indigenous-Settler History. In T. C.A \& C. Hughes (Eds.), Posthuman Research Practices in Education. London, UK: Palgrave Macmillan.

Lester, P., \& Flake, E. (2013). How wartime military service affects children and families. The future of children, 23(2), 121-141.

Macías, T. (2015). "Between a rock and a hard place": Negotiating the neoliberal regulation of social work practice and education. Alternative Routes, 26, 251-276.

MacNaughton, G., \& Frey, D. (2015). Teaching the transformative agenda of the Universal Declaration of Human Rights. Radical Teacher, 103(Fall), 17-25. doi:10.5195/rt.2015.232

Maloney, M., Sims, M., Rothe, A., Buettner, C., Sonter, L., Waniganayake, M., ... Girlich, S. (2019). Resisting neoliberalism: Professionalisation of early childhood education and care. International Journal of Elementary Education, 8(4), 1-10. doi:10.11648/j.ijeedu.20190801.11

Mayo, N. (2019). University staff 'at breaking point' as counselling demand soars: Hepi report ties increase to mounting workloads and performance management. Retrieved from https://www.timeshighereducation. com/news/university-staff-breaking-pointcounselling-demand-soars

Mazzoni, V., \& Harcourt, D. (2013). An international experience of research with children: Moving forward on the idea of children's participation. Qualitative Research. doi:10.1177/1468794112468470

McLaren, P. (2005). Critical Pedagogy and Class Struggle in the Age of Neoliberal Globalization: Notes from History's Underside. International Journal of Critical Democracy, 2(1), 1-24.

Millei, Z., \& Jones, A. (2014). The Australian Early Childhood Curriculum and a Cosmopolitan Imaginary. International Journal of Early Childhood, 46, 63-79. doi:10.1007/s13158-0140100-2

Millei, Z., \& Kallio, K. P. (2018). Recognizing politics in the nursery: Early childhood education institutions as sites of mundane politics. Contemporary Issues in Early Childhood, 19(1), 
31-47. doi:10.1177/1463949116677498

Monbiot, G. (Producer). (2019, 9.8.19). The new political story that could change everything. TEDSummit 2019.

Moore, P. , and A.Robinson . 2016. "The Quantified Self: What Counts in the Neoliberal Workplace." New Media \& Society 18 (11): 2774-2792. doi: $10.1177 / 1461444815604328$

Moss, P. (2014). Transformative change and real utopias in early childhood education: A story of democracy, experimentation and potentiality: A story of democracy, experimentation and potentiality(pp. 7 pages downloaded).

Newman, L., \& Pollnitz, L. (2005). Working with children and families: Professional, legal and ethical issues. Frenchs Forrest, NSW: Pearson Education Australia

NSW Education Standards Authority. (2014). Australian professional standards for teachers. Sydney, Australia: NSW Government

Otto, H., \& Keller, H. (2014). Epilogue: The future of attachment. In H. Otto \& H. Keller (Eds.), Different faces of attachment: Cultural variations on a universal human need (pp. 307-312). Cambridge, UK: Cambridge University Press.

Page, S. (2019). The wage rates are too low and turnover is too high. The Spoke.

Paris, R., DeVoe, E., Ross, A., \& Acker, M. (2010). When a parent goes to war: Effects of parental deployment on very young children and implications for intervention. American Journal of Orthopsychiatry, 80(4), 610-618.

Penn, H. (2002). The World Bank's view of early childhood. Childhood, 9(1), 118-132. doi:10.1177/0907568202009001008

Press, F., Woodrow, C., Logan, H., \& Mitchell, L. (2018). Can we belong in a neo-liberal world? Neo-liberalism in early childhood education and care policy in Australia and New Zealand. Contemporary Issues in Early Childhood, 19(4), 328-339. doi:https://doi.org/10.1177/1463949118781909

Rea, J. (2018). Breaking the culture of overwork. NTEU Advocate, 25(1), 40-41.

Rogers, M. (2017). Young children's understanding and experiences of parental deployment within an Australian Defence Force family. School of Education. Armidale, Australia, University of
New England. Doctor of Philosophy. 10.13140/ RG.2.2.26497.61281 Retrieved from https://hdl. handle.net/1959.11/27661

Rogers, M. (2018a). Listening to children's voices through art: Communicating experiences and understandings in Mosaic research. International Art in Early Childhood Research Journal, 1(1), 1-19. http://artinearlychildhood.org/ journals/2018/ARTEC_2018_Research_Journal_1_ Article_5_Roger.pdf

Rogers, M. (2018b). Now that I am big: Anthony's story (M. Fussell Ed.). Canberra, Australia: Defence Community Organisation, Department of Defence. http://www.defence.gov.au/DCO/_ Master/documents/Books/Anthonys-Story.pdf

Rogers, M. (2019). Harnessing the power of cultural health narratives when working with parents of young children. Children Australia, 44(3), 105109. doi:10.1017/cha.2019.22

Rogers, M. (2020). Recommendations to support young children from Australian military families: A report for policy makers, family and social workers and educators Journal of Management Policy and Practices, 21(2), 1-26. doi:https://doi. org/10.33423/jmpp.v21i2

Rogers, M. (2021). Why telling stories could be a more powerful way of convincing some people to take a COVID vaccine than just the facts. The Conversation. Retrieved from https://theconversation.com/why-tellingstories-could-be-a-more-powerful-way-ofconvincing-some-people-to-take-a-covidvaccine-than-just-the-facts- 155050

Rogers-Baber, M. (2017). Protective factors in families: Themes from a socio-ecological study of Australian Defence Force families experiencing parental deployment. SAGE Open Access, 7(2). doi:10.1177/2158244017706711. Retrieved from http://journals.sagepub.com/doi/ full/10.1177/2158244017706711

Rogers, M., \& Bird, J. (2020). Children's agency: Developing a digital app to voice family narratives. Journal of Military, Veteran and Family Health, 6(2), 129-137. doi:10.3138/ jmvfh-2019-0022

Rogers, M., Bird, J., \& Sims, M. (2019). Using the media arts to digitally support young children's family and cultural narratives. International Art in Early Childhood Research Journal, 1(1), 1-16. http://artinearlychildhood.org/wp-content/ uploads/2019/12/ARTEC_2019_Research_ 


\section{iejee}

Journal_1_Article_3_Rogers_Bird_Sims.pdf

Rogers, M., \& Boyd, W. (2020). Meddling with Mosaic: Reflections and adaptations European Early Childhood Education Research Journal. doi:10. 1080/1350293X.2020.1817236

Rogers, M., Dovigo, F., \& Doan, L. (2020). Educator identity in a neoliberal context: recognising and supporting early childhood education and care educators. European early childhood education research journal, 28(6), 806-822. doi:1 $0.1080 / 1350293 \times .2020 .1836583$

Rogers, M., Sims, M., Bird, J., \& Elliott, S. (2020). Organisational narratives $v s$ the lived neoliberal reality: Tales from a regional university. Australian Universities' Review, 62(2). Retrieved from http://www.aur.org.au/ article/Organisational-narratives-vs-the-livedneoliberal-reality\%3A-Tales-from-a-regionaluniversity-\%28AUR-62-01\%29-21824

Segal, M. W. (1986). The military and the family as greedy institutions. Armed Forces \& Society, 13(1), 9-38. doi:10.1177/0095327X8601300101

Sims, M. (2011). Social inclusion and the Early Years Learning Framework: A way of working. Mt Victoria, Australia: Pademelon Press.

Sims, M. (2014). Racism? Surely not. Australian Journal of Early Childhood, 39(1), 89-93.

Sims, M. (2017). Neoliberalism and early childhood. Cogent Education. Cogent Education, 4(1), 136411. doi:10.1080/2331186X.2017.1365411

Sims, M. (2020). Bullshit towers: Neoliberalism and managerialism in universities in Australia. Oxford, UK: Peter Lang.

Sims, M., \& Waniganayake, M. (2015). The performance of compliance in early childhood: Neoliberalism and nice ladies. Global Studies in Childhood, 5(3), 333-345. doi:10.1177/2043610615597154

Tertiary Education Quality and Standards Agency. (2015). Higher Education Standards Framework. Acts and Standards. Retrieved from https:// www.teqsa.gov.au/higher-educationstandards-framework-2015

United Nations. (1989). Convention on the Rights of the Child. Retrieved from https://www.ohchr.org/ en/professionalinterest/pages/crc.aspx

Via Institute of Character. (2021). Strengths by virtue. The 24 character strengths. Retrieved from https://www.viacharacter.org/characterstrengths

Vintimilla, C. (2014). Neoliberal Fun and Happiness in Early Childhood Education. Canadian Children, 39, 79-87.

Watts, R. (2017). Public universities, managerialism and the value of higher education. London, UK: Palgrave Critical University Studies. 